ISSN 0258-7122 (Print), 2408-8293 (Online)

Bangladesh J. Agril. Res. 44(4): 641-648, December 2019

\title{
IN VITRO PROPAGATION OF POPULAR BANANA CULTIVAR (Musa spp. cv. Patakpura)
}

\author{
BANDITA DEO ${ }^{1}$, BIKRAM KESHARI ${ }^{2}$ AND BIKRAM PRADHAN ${ }^{3}$
}

\begin{abstract}
The present experiment was conducted to optimize protocols for in vitro propagation of banana (Musa sp.) cv. 'Patakpura' (AAB), supplemented with different growth regulators. Shoot tips obtained from sword suckers were cultured aseptically on MS medium supplemented with different concentrations of cytokinins like 6-Benzylaminopurine (BAP) and Kinetin (KN) for multiplication of shootsand auxins such as indole acetic acid (IAA) and naphthalene acetic acid (NAA) for induction of roots. The best result from the initial culture was obtained from MS medium supplimented with $4 \mathrm{mg} / \mathrm{l} \mathrm{BAP}+$ $0.5 \mathrm{mg} / \mathrm{l} \mathrm{IAA}$. The highest shoot fresh weight, shoot length and number of shoots per explant were recorded from MS medium supplemented with $4 \mathrm{mg} / \mathrm{l}$ $\mathrm{BAP}+0.5 \mathrm{mg} / \mathrm{l} \mathrm{IAA}+0.25 \mathrm{mg} / \mathrm{l} \mathrm{NAA}$. Therefore, the MS medium supplemented with $4 \mathrm{mg} / \mathrm{l} \mathrm{BAP}+0.5 \mathrm{mg} / \mathrm{l} \mathrm{IAA}+0.25 \mathrm{mg} / \mathrm{l} \mathrm{NAA}$ was found to be most effective and productive combination for shoot multiplication and proliferation of the culture in vitro. IAA at a concentration of $1 \mathrm{mg} / \mathrm{l}$ was found to be most suitable for rooting of the shoots.
\end{abstract}

Keywords: Musa; in vitro; micro propagation; MS medium; phytohormones.

\section{Introduction}

Cultivated banana is derived from two diploid species of genus Musa acuminata X Musa balbisiana. Banana and plantain approximately account for 21-22\% of the fresh fruit production of the world and is one of the major economic crops. It is world's second largest fruit crop and fourth most important global food crop which is produced over 100 million metric tons per year (Banana Market Review and Banana Statistics 2012-2013, FAO, 2014). India, the largest banana producer in the world, has been rapidly increasing cultivated area and volumes of production over the past decade. Although India currently produces predominantly for the domestic market, it also supplies bananas to other countries. The 'Patakpura' variety of Odisha belongs to Musa pradisiaca (Musa pradisiaca $=$ hybrid between Musa acuminata and Musa balbisiana) having the genotype of $\mathrm{AAB}$ and is among one of the most popular local banana cultivars of Odisha which have a very high demand in the markets of many states of India.

Researchers have found that fruits of banana contain various antioxidants such as vitamin C, vitamin E and $\beta$-carotene (Kanazawa and Sakakibara, 2000). It has

\footnotetext{
${ }^{1,2,3}$ Plant Physiology and Biochemistry Division, Regional Plant Resource Centre, Bhubaneswar, Odisha, India.
} 
been reported that the fruit has been used as anti-scorbutic, aphrodisiac and diuretic (Salawu et al., 2010). It also contains dopamine, a powerful antioxidant, and all the B group vitamins present in the plant kingdom [Banana inter professional association (AIB), 2014]. Thus bananas contribute to the proper functioning of energy metabolism and the nervous system and to maintain of good digestive transit in human (Aprifel, 2015).

Banana species are normally propagated through vegetative parts (suckers) because all the cultivated banana varieties are triploid and have sterile seeds (Muhammad et al., 2013). Conventional vegetative means of banana propagation was noted to have several negative impacts which include diseases transmission, low production, very slow rate of multiplication of suckers and poor preservation of original plant genetic material (Hussein, 2012).The cultivation of 'Patakpura' is mostly restricted to the coastal areas of Odisha. Mainly it is affected with diseases like panama wilt and banana streak disease. In conventional method adequate numbers of suckers are not available. Transfer of diseases through suckers is also one of its major drawbacks. The disadvantages arising from conventional propagation can be terminated by propagating banana through in vitro propagation (tissue culture) which offers clean planting material by mass propagation (Ali et al., 2011).

Previously many researchers reported rapid regeneration of Musa sp. through in vitro propagation (Nauyen \& Kozai, 2001; Krishnamoorthy et al., 2001; Roels et al., 2005). Cytokinins and auxins play key role in in vitro culture as the later are concerned with root formation, the former is mainly required for shoot formation and growth of buds. Cytokinins such as benzyl aminopurine (BAP) and kinetin are known to reduce the apical meristem dominance and induce both auxiliary and adventitious shoot formation from meristematic explants in banana (Khalid, 2011).

The presences of BAP inhigher concentrations inhibit elongation of adventitious meristems and developmentinto complete plants (Buising, 1994). Auxins and other growth regulators such as gibberellins play important roles in the growth and differentiation of cultured cells and tissues (Alexandrova, 1996). The present study was undertaken for optimization of protocols for rapid multiplication of 'Patakpura' banana on using Murashige and Skoog medium supplimented with different plant growth regulators.

\section{Materials and Methods}

The present study was conducted in Banana Tissue Culture laboratory, Regional Plant Resource Centre, Bhubaneswar, Odisha, India. Sword suckers with an average height of 30-45 cm and with of $3 \mathrm{~cm}$ of selected plants from eastern coasts of Odisha was collected and the rhizomes were selected as explant. Suckers for initial tissue culture were collected in the month of July, 2017 and it took 8 months for completion of in vitro propagation of Patakpura. Explants were 
processed by cutting the corm portion of the suckers into cylindrical shape of 4-5 $\mathrm{cm}$ in height and $2 \mathrm{~cm}$ in diameter. Then the explants were washed with detergent (Labolene) and treated with Bavistin for 45 mins. Surface sterilization with $0.5 \%$ Sodium hypochloride for 30 mins was done followed bywashing thrice in sterile distilled water in aseptic condition (under Laminar Air flow). The explants were inoculated aseptically in MS Medium (Murashige and Skoog, 1962).

The growth regulators used for shoot culture studies were Benzyl Amino Purine (BAP), Kinetin (KN), Indole-3-acetic acid (IAA) and Naphtalene acetic acid (NAA). For the initial culture the concentration and combination of plant growth regulators used with MS medium were as follows: $2 \mathrm{mg} / \mathrm{l} \mathrm{BAP}+0.5 \mathrm{mg} / \mathrm{l} \mathrm{IAA}$ $\left(\mathrm{P}_{1}\right), 4 \mathrm{mg} / \mathrm{l} \mathrm{BAP}+0.5 \mathrm{mg} / \mathrm{l} \mathrm{IAA}\left(\mathrm{P}_{2}\right), 8 \mathrm{mg} / \mathrm{l} \mathrm{BAP}+0.5 \mathrm{mg} / \mathrm{l} \mathrm{IAA}\left(\mathrm{P}_{3}\right), 5 \mathrm{mg} / \mathrm{l}$ $\mathrm{KN}+0.5 \mathrm{mg} / \mathrm{l} \mathrm{IAA}\left(\mathrm{P}_{4}\right)$ and $10 \mathrm{mg} / \mathrm{l} \mathrm{KN}+0.5 \mathrm{mg} / \mathrm{l}$ IAA $\left(\mathrm{P}_{5}\right)$. Different concentrations of growth regulators supplemented in MS medium during multiplication culture of Musa spp. cv. 'Patakpura' explants were as follows: 2 $\mathrm{mg} / \mathrm{l} \mathrm{BAP}+0.5 \mathrm{mg} / \mathrm{l} \mathrm{IAA}\left(\mathrm{T}_{1}\right), 4 \mathrm{mg} / \mathrm{l} \mathrm{BAP}+0.5 \mathrm{mg} / \mathrm{l} \mathrm{IAA}\left(\mathrm{T}_{2}\right), 2 \mathrm{mg} / \mathrm{l} \mathrm{BAP}+$ $0.5 \mathrm{mg} / \mathrm{l} \mathrm{IAA}+0.25 \mathrm{mg} / \mathrm{l} \mathrm{NAA}\left(\mathrm{T}_{3}\right), 4 \mathrm{mg} / \mathrm{l} \mathrm{BAP}+0.5 \mathrm{mg} / \mathrm{l} \mathrm{IAA}+0.25 \mathrm{mg} / \mathrm{l}$ NAA ( $\left.\mathrm{T}_{4}\right), 2 \mathrm{mg} / \mathrm{l} \mathrm{KN}+0.5 \mathrm{mg} / \mathrm{l} \mathrm{IAA}+0.25 \mathrm{mg} / \mathrm{l} \mathrm{NAA}\left(\mathrm{T}_{5}\right), 4 \mathrm{mg} / \mathrm{l} \mathrm{KN}+0.5$ $\mathrm{mg} / \mathrm{l} \mathrm{IAA}+0.25 \mathrm{mg} / \mathrm{l} \mathrm{NAA}\left(\mathrm{T}_{6}\right), 1 \mathrm{mg} / \mathrm{l} \mathrm{BAP}+1 \mathrm{mg} / \mathrm{l} \mathrm{KN}+0.5 \mathrm{mg} / \mathrm{l} \mathrm{IAA}+$ $0.25 \mathrm{mg} / \mathrm{l} \mathrm{NAA}\left(\mathrm{T}_{7}\right)$ and $2 \mathrm{mg} / \mathrm{l} \mathrm{BAP}+2 \mathrm{mg} / \mathrm{l} \mathrm{KN}+0.5 \mathrm{mg} / \mathrm{l} \mathrm{IAA}+0.25 \mathrm{mg} / \mathrm{l}$ NAA $\left(\mathrm{T}_{8}\right)$. MS media supplimented with three concentration of IAA such as 0.5 $\mathrm{mg} / \mathrm{L}\left(\mathrm{R}_{1}\right), 1.0 \mathrm{mg} / \mathrm{L}\left(\mathrm{R}_{2}\right)$ and $2.0 \mathrm{mg} / \mathrm{L}\left(\mathrm{R}_{3}\right)$ were used for root development.

At first the explants were grown on initial culture medium for 15 days. Then the initial culture were transferred to multiplication culture stage. During multiplication stage the explants were cultured up to six sub-cultures and in each sub-culture the explants were grown on MS media for 21 days. After formation of individual shoots the explants were the culture in rooting medium for root development. All of the explants were cultured on MS media solidified with agar $(6.5 \mathrm{gm} / \mathrm{L})$. After preparation of MS media the $\mathrm{pH}$ was adjusted to $5.75-5.8$ by using $1 \% \mathrm{NaOH}$ or $1 \% \mathrm{HCl}$, which is suitable for the growth of cultured plantlets during in vitro culture before autoclaving the media for $15-20 \mathrm{mins}$ at $121^{\circ} \mathrm{C}$ and 15 PSI. The culture bottles containing the explants were kept in culture rack. For each treatment twenty explants were taken into consideration.

The culture room was maintained at $22^{\circ} \mathrm{C}$ to $25^{\circ} \mathrm{C}, 16 \mathrm{hr}$ photo period of 35 $50 \mu \mathrm{Em}-2 \mathrm{~s}-1$ intensity provided by cool white fluorescent tubes. After the root formation the banana plantlets were transferred to green house for primary hardening. The plantlets were planted in soilrite inside the primary hardening chamber and watered regularly. After primary hardening for 2-3 weeks the plantlets were transferred to polybags in secondary hardening containing soil, sand and FYM in the ratio 1:1:1.

The experiment was repeated thrice for confirmation of findings. The data collected at different stages of the experiment were analysed in MS Excel to find mean and standard error. 


\section{Results and Discussion}

The explants were inoculated on MS medium with different concentration and combination of plant growth regulators (Auxins and Cytokinins). During the initial stage the rate of contamination remained high $(10 \%)$ because the suckers were obtained directly from soil. After 20-30 minutes of inoculation secretion of phenolic compound was observed on the whitish portion of the explant as it turned into light brown in colour. After 1 week of cultureall explants in initial mediums became enlarged and changed to greenish in colour.

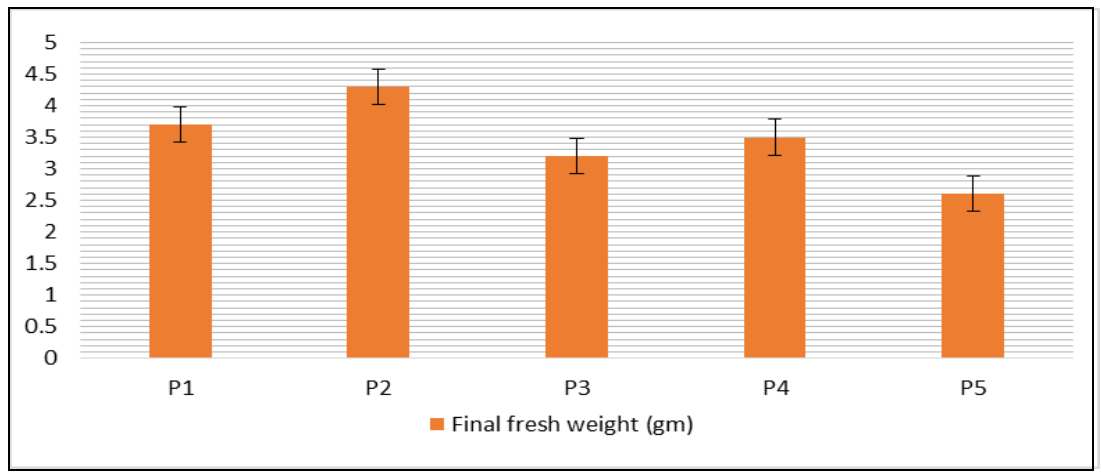

Figure 1: Growth of Musa cv. 'Patakpura' explants during initial culture after 2 weeks of inoculation.
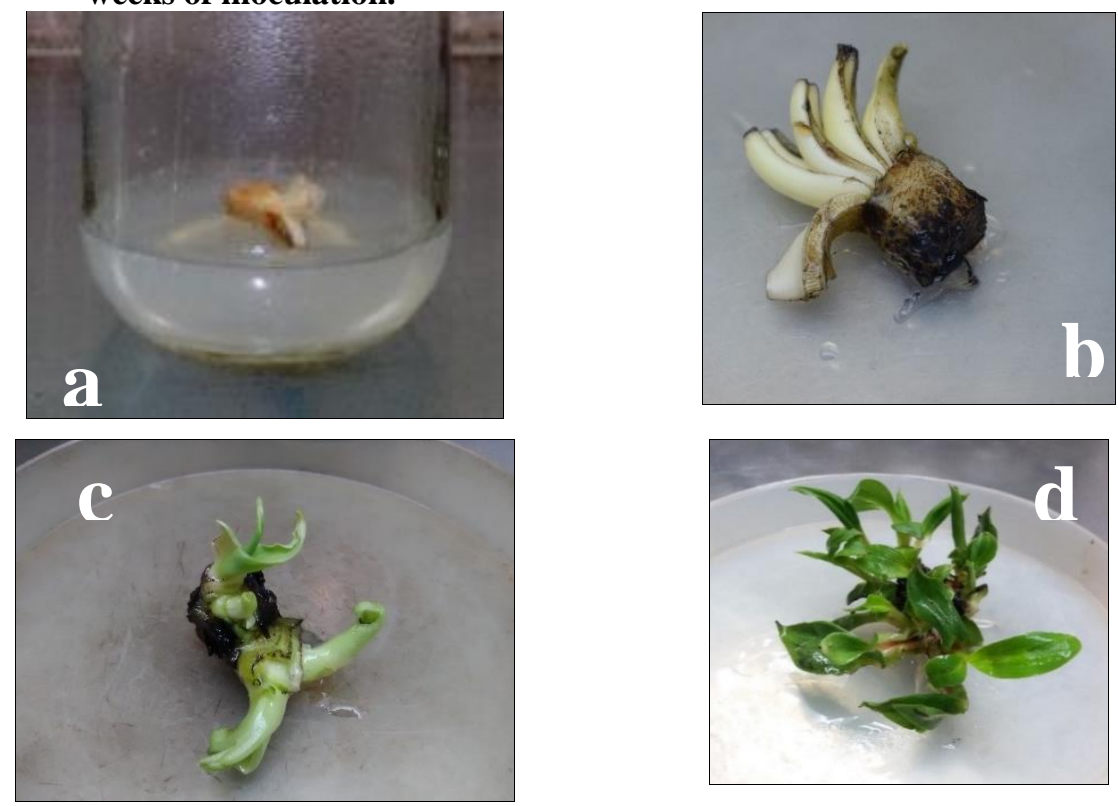

Fig. 2. a- Musa cv. 'Patakpura' explant on initial culture medium and b- Growth after 15 days of inoculation, c- 'Patakpura' explants cultured on medium containing with $2 \mathrm{mg} / \mathrm{l} \mathrm{KN}+0.5 \mathrm{mg} / \mathrm{l} \mathrm{IAA}+0.25 \mathrm{mg} / \mathrm{l} \mathrm{NAA}$, d-Explants cultured on medium containing with $4 \mathrm{mg} / \mathrm{l} \mathrm{BAP}+0.5 \mathrm{mg} / \mathrm{l} \mathrm{IAA}+0.25 \mathrm{mg} / \mathrm{l} \mathrm{NAA}$. 
Best response from the initial cultures was obtained on medium supplimented with $4 \mathrm{mg} / \mathrm{L}$ BAP where explants showed better growth and proliferations in comparison to other media. Cytokinins like benzylaminopurine (BAP) and kinetin play significant role to reduce the apical meristem dominance and induce both auxiliary and adventitious shoot formation from meristematic explants in banana (Khalid, 2011). Highest final fresh weight $(4.3 \pm 0.18 \mathrm{gm})$ was observed fromexplants in $4 \mathrm{mg} / \mathrm{L} \mathrm{BAP}+0.5 \mathrm{mg} / \mathrm{L}$ IAA medium (P2). Poor response was observed in explants grown on medium with high Kinetin content $(10 \mathrm{mg} / \mathrm{L})$, producing least final fresh weight $(2.6 \pm 0.18 \mathrm{gm})$ among all the explants cultured on other media.Explants exhibited vigorous proliferation in lower concentration of BAP in comparison to Kinetin. Venkatachalam et al., 2007 and Farahani et al., 2008 reported the importance of BAP than other cytokinins in inducing growth of shoot tip cultures in different cultivars of bananas. Rahman et al., 2006 and Dhed'a et al., 1991 reported that BAP has a remarkable effect in inducing the growth of axillary and adventitious buds and foliar development of shoot tip cultures.During Multiplication stage growth and proliferation of explants were seen after 6-7 days after inoculation in all the 8 different media compositions.

Table 1. Effect of plant growth regulators on shoot proliferation of 'Patakpura'.

\begin{tabular}{c|c|c|c}
\hline Medium Code & $\begin{array}{c}\text { Avg. Fresh Weight } \\
(\mathbf{g m})\end{array}$ & $\begin{array}{c}\text { Avg. Shoot Length } \\
(\mathbf{c m})\end{array}$ & $\begin{array}{c}\text { Avg. Number of } \\
\text { shoot }\end{array}$ \\
\hline T1 & 5.29 & 2.9 & 6.9 \\
T2 & 6.15 & 3.75 & 7.1 \\
T3 & 6.81 & 3.17 & 9.37 \\
T4 & 8.53 & 3.61 & 13.57 \\
T5 & 4.78 & 2.89 & 5.8 \\
T6 & 5.38 & 2.35 & 6.57 \\
T7 & 5.77 & 3.1 & 8.7 \\
T8 & 5.21 & 3.31 & 11.9 \\
\hline
\end{tabular}

The lowest shoot buds number as well as percentage of response $(50 \%)$ was marked in culture medium supplied with $2 \mathrm{mg} / \mathrm{L} \mathrm{KN}$. Media containing only BAP and IAA were marked by inducing shoot proliferation. Better results were obtained when explants cultured on medium containing BAP along with IAA and NAA. The highest number of shoot (13) was observed in explants cultured on medium supplied with $4 \mathrm{mg} / \mathrm{l} \mathrm{BAP}+0.5 \mathrm{mg} / \mathrm{l} \mathrm{IAA}+0.25 \mathrm{mg} / \mathrm{l}$ NAA (T4). 
Table 2. Effect of plant growth regulators on root induction of 'Patakpura'.

\begin{tabular}{c|c|c|c}
\hline Parameters & \multicolumn{3}{c}{ Medium Code } \\
\cline { 2 - 4 } & $\mathbf{R 1}$ & $\mathbf{R 2}$ & $\mathbf{R 3}$ \\
\hline Average no. of roots per shoot & 4 & 6 & 6 \\
Average root length (cm) & 4 & 5 & 3 \\
Average shoot length (cm) & 5 & 4 & 4 \\
Average no. of leaves per shoot & 3 & 4 & 4 \\
\hline
\end{tabular}

Robert et al., (2013) reported that the highest multiple shoot induction was found in $\mathrm{MS}+5 \mathrm{mg} / \mathrm{l} \mathrm{BAP}$ while $\mathrm{MS}+1 \mathrm{mg} / \mathrm{l} \mathrm{NAA}+0.2 \mathrm{mg} / \mathrm{l} \mathrm{BAP}$ gave the longest regenerated shoots after 45 days of incubation. The developed shoots were cultured in MS medium with different auxin concentrations for root induction and growth. Previously Wong (1986) stated that by increasing the concentration of BAP the production of shoots per explants was also increased. Devendrakumar et al., 2013 studied that use of BAP at $20 \mu \mathrm{M} / \mathrm{L}$ showed better results in comparison to its low and high concentrations for shoot induction and proliferation.
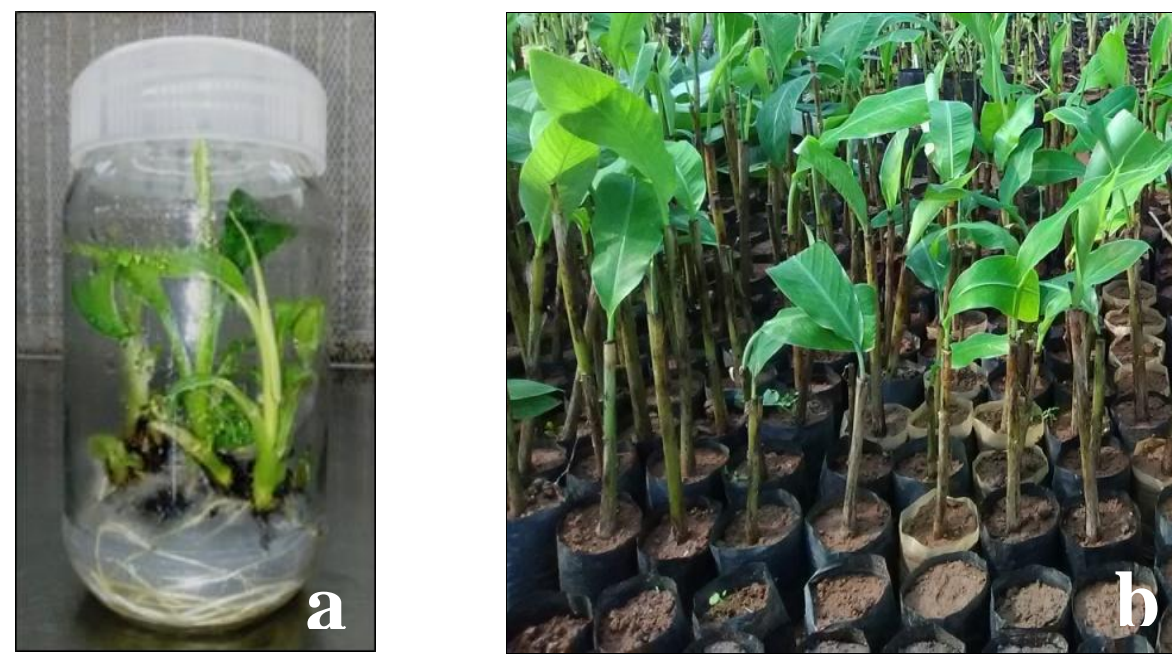

Fig. 3. a- Root induction of 'Patakpura' shoots supplimented with IAA (1 mg/l); b- Tissue cultured 'Patakpura' plants in RPRC nursery.

The best response for root induction was observed in MS medium containing 1 $\mathrm{mg} / \mathrm{l} \mathrm{IAA}$. In an average of $6 \pm 0.95$ roots per shoot was observed in $1 \mathrm{mg} / \mathrm{L}$ IAA medium within 8 days of culture, and the average length of roots was $5 \pm 1.61$ $\mathrm{cm}$. Auxins such as Indole -3-acetic acid (IAA) and Naphtalene acetic acid (NAA) have been reported to promote plant rooting in vitro (Vuylsteke, 1989). Auxins also play vital roles in the growth and differentiation of cultured cells and tissues (Bohidar et al., 2008; Ngomuo et al., 2014). 


\section{Conclusion}

From the present study it was observed that the response of 'Patakpura' banana explants was better when cultured in medium containing BAP in comparison to Kinetin during initial as well as in the multiplication stages. It was observed that auxins like IAA and NAA also play a vital role in shoot formation during proliferation stages. The uses of auxins are very much essential during in vitro culture of banana as they are involved in root formation and proliferation. The optimum concentrations of growth regulators for initial and shoot multiplication during in vitro culture of 'Patakpura' banana were $4 \mathrm{mg} / \mathrm{l} \mathrm{BAP}+0.5 \mathrm{mg} / \mathrm{l} \mathrm{IAA}$ and $4 \mathrm{mg} / \mathrm{l} \mathrm{BAP}+0.5 \mathrm{mg} / \mathrm{lAA}+0.25 \mathrm{mg} / \mathrm{l} \mathrm{NAA}$ respectively.

\section{Acknowledgement}

Authors are thankful to Government of Odisha, Department of Forest and Environment for funding and Regional Plant Resource Centre for providing facilities to carry out the research studies.

\section{Reference}

Alexandrova, K., P., Denchev and B., Conger. 1996. Micropropagation of Switchgrass by Node Culture. Crop Science. 36:1709-1711.

Ali, A., A., Sajid, N.H., Naveed, A., Majid, A., Saleem, U.A., Khan, F.I. Jafery and S., Naz. 2011. Initiation, Proliferation and Development of Micro-Propagation System for Mass Scale Production of Banana through Meristem Culture. African Journal of Biotechnology.10:15731-15738.

Aprifel. 2015 : http://www.aprifel.com/fiche-nutri-produit-allegations-banane,24.html

Banana interprofessional association (AIB). 2014. «Fiche 1: La bananeenchiffres», Recueil de fiches de qualité de la banane. CIRAD, France.

Bohidar, S., M. Thirunavoukkarasu and T. Rao. 2008. Effect of Plant Growth Regulators On In Vitro Micropropagation of 'Garden Rue' (Ruta graveolens L.). International Journal of Integrative Biology. 3:36-43.

Buising, C.M., R.C., Shoemaker and R.M., Benbow. 1994. Early Events of Multiple Bud Formation and Shoot Development in Soybean Embryonic Axes Treated with the Cytokinin, 6-Benzylaminopurine. American Journal of Botany. 81:1435-1448.

Dhed'a, D., F., Dumortier, B., Panis, D., Vuylsteke and E., De Langhe. 1991. Plant regeneration in cell suspension cultures of cooking banana 'Bluggoe' cultivar (Musa spp. ABB group). Fruits. 46: 125-135.

FAO. 2014. Food and Agricultural Organization of the United Nations.Banana Market Review and Banana Statistics 2012-2013.

Farahani F., H., Aminpoor, M., Sheidai,Z., Noormohammadi, M.H., Mazinani. 2008. An Improved System for in vitro Propagation of Banana (Musa acuminate L.) Cultivars. Asian J. Plant Sci. 7(1):116 -118.

Hussein, N. 2012. Effects of Nutrient Media Constituents on Growth and Development of Banana (Musa spp.) Shoot Tips Cultured in Vitro. African Journal of Biotechnology.11:9001-9006. 
Kanazawa, K. and H., Sakakibara. 2000. High content of dopamine, a strong antioxidant, in Cavendish banana. J. Agric. Food Chem. 48(3): 844-848.

Khalid, N. 2011. Effect of Benzylaminopurine (BAP) Pulsing on in Vitro Shoot Multiplication of Musa acuminata (Banana) cv. Berangan. African Journal of Biotechnology. 10:2446-2450

Krishnamoorthy, V., N., Kumar, K., Sooriananthasundaram. 2001. In vitro propagation of the popular desert cv. Poovan (AAB). First post graduate seminar. TNAU, Coimbatore. 46.

Muhammad M.I., A., Muhammad, I., Hussain, H., Bilal. 2013. "Optimization of In Vitro Micropropagation Protocol for Banana (Musa Sapientum L.) Under Different Hormonal Concentrations and Growth Media". IJAIR. 2(1): 23-27.

Murashige, T. and F., Skoog. 1962. A revised medium for rapid growth and bioassays with tobacco tissue culture. Physiol Plant., 15: 473 - 497.

Nauyen, O. T., and T., Kozai. 2001. Growth of in vitro banana (Musa sp.).Shoots under photomixotrophic and photoautotrophic conditions. In-vitro cell. Dev. Bio. Plants. 37: 824-829.

Ngomuo, M., E., Mneney, P.A., Ndakidemi. 2014. The in Vitro Propagation Techniques for Producing Banana Using Shoot Tip Cultures. American Journal of Plant Sciences. 5: 1614-1622.

Rahman , M.Z., M.G. Sharoar, M.N. Matin , M.H. Rahman, M.M. Rahman and M.R. Islam. 2006. High frequency plant regeneration of a dessert banana cv. Mehersagar for commercial exploitation. Biotechnology. 5: 296-300.

Robert, L., H., Vanlaldiki and W. I., Meitei. 2013. In vitro shoot tip culture of banana cultivar meiteihei. The Bioscan. 8(3): 839-844.

Roels, S., M., EScalona, I., Cejas, C., Noceda, R., Rodriguez, M. J., Canal and D., Sandoval. 2005. Optimization of plantain (Musa AAB) micropropagation by temporary immersion system. Plant Cell Tissue Organ Cult. 82: 57-66.

Salawu, L., R. A., Bolarinwa, A. B., Adegunloye and H. A., Moraine. 2010. HBs Ag, anti-HCV, anti-HIV and VDRL in blood donors: Prevalence and trends in the last three and a half years in a tertiary health care facility in Ile-Ife, Nigeria. Int. J. Med. Sci. 2(11): 335-341.

Venkatachalam, L., R. V., Sreedhar and N., Bhagyalakshmi. 2007. "Micro Propagation in Banana Using High Levels Does Not Involve Any Genetic Change as Revealed by RAPD and ISSR Markers". Plant Growth Regulation. 51(3):192-205.

Vuylsteke, D. R. 1989. Shoot-Tip Culture for the Propagation, Conservation and Exchange of Musa germplasm.

Wong, W.C. 1986. In vito propagation of banana (Musa spp.): Initiation, Proliferation and Development of Shoot - tip cultures on defined media. Plant Cell, Tissue and Organ Culture. 6:159- 166. 